\title{
Determining the Ideal Election Model at the Provincial Level: Case Study of the Southeast Sulawesi Regional Head Election in 2018
}

\author{
Teguh Setyabudi ${ }^{1}$, Sampara Lukman ${ }^{2}$, Aries Djaenuri ${ }^{3}$, Khasan Effendy $^{4}$ \\ 1,2,3,4 Institut Pemerintahan Dalam Negeri (IPDN), Indonesia \\ Email: teguh.setyabudi@gmail.com
}

\begin{abstract}
This research was conducted to find the right model in the provincial head elections. This is based on the many deficiencies that occur when direct regional head elections are held such as multiple voter lists, logistical problems, low capacity of organizers, the emergence of SARA issues, strong money politics, bureaucratic politicization, and low participation in voting for the community (Pilkada Case Study Southeast Sulawesi 2018). This research encourages the alternative model of the governor and deputy governor election. Furthermore, if you want to be applied in Indonesia in general, more research needs to be done. First, improvements in the overall stages of governors and deputy governors' elections and the use of information technology to increase transparency, accountability, and efficiency. Second, the governor and the deputy governor's election is still carried out directly by tightening the nomination requirements. Among other things, they must participate in the regeneration of political parties, have experience and knowledge of government and local characteristics of the region, and are indigenous people who have lived long in the area. Third, the governor is still directly elected by the community, while the deputy governor can be proposed by the governor to the DPRD/MOHA from the private sector/ASN who meet special requirements, namely experience in government and knowledge of the local characteristics of the region.
\end{abstract}

Keywords: Democracy, Election, Governor.

\section{A. INTRODUCTION}

Indonesia is still seeking democratic practices, especially at the local level, according to the nation's identity. During the old order (1945-1965), Indonesia had indirectly implemented a democratic mechanism when the president and regional head were elected by the legislature. Conditions were almost the same also happens in the New Order era in 1966-1998. Even though the political system at that time was authoritarian, the mechanism in the selection of political leadership at all levels did not change much. Executives (presidents and regional heads) are still elected through community representations that have previously been elected and sit as people's representatives in certain areas, both in the People's Consultative Assembly (MPR), the People's Representative Council (DPR), and the Regional People's Representative Council (DPRD).

Significant changes have only occurred after the new order collapsed in 1998 when the people could directly elect the president and regional heads. Referring to the applicable regulations (Law No. 32 of 2014), the direct election only began to be 
implemented in 2005 for several reasons that developed at that time. Over time, one of the decisions of the Constitutional Court (MK) stated that the election regulation was part of the electoral regime, not the regional government regime. Therefore, the elections are encouraged in tune with the presidential/vice-presidential elections, which have already been conducted directly by the people. The decision directly affected the efforts to revise Law Number 32 of 2004 concerning the Regional Government and substantial changes to the local election.

However, lately, the discourse of changes in the system of regional head elections, especially at the provincial level, has strengthened. This condition arises by referring to the constitution of the 1945 Constitution article 18 paragraph 4 , which states that the governor, regent, and mayor as the head of regional government are democratically elected. Many parties interpret that the word democratic in that phrase can be interpreted as being chosen directly by the people and or elected through their representatives, namely the DPRD. The implication is that policymakers are encouraged to restore the position of the DPRD as a representative of the local assembly to re-elect the regional head through Law No. 22 of 2014 concerning the local elections that are designed for this purpose. The effort did not go because it did not take place long after the outlaw was passed, President Soesilo Bambang Yudhoyono issued Government Regulation in Lieu of Law No. 1 of 2014. As a result, the implementation of the elections was returned to the people directly.

The emergence of efforts to restore local election arrangements to the DPRD is inseparable from the practice of direct elections, which are considered to have caused a heap of new problems. At the technical level, for example, field identification by Fatoni et al. (2010) states that there are problems in the aspects of voter registration, registration and determination of regional heads and deputy regional heads, campaigns, voting and vote counting, and the commitment and endorsement of elected candidate pairs ${ }^{10}$. The empirical reality has so far been relatively resolved by the KPUD through technical efforts in the field. There are several problems on a broader scale, as noted by Haris (2005). Likewise, Bisri et al. (2006) note on two crucial issues relating to the impact of political liberalization that presents strong candidates for capital and strengthened executive dominance.

\section{B. LITERATURE REVIEW}

\section{General election}

Elections are arenas of political competition involving public participation through a free, fair, honest, open, and peaceful process without violence. Elections are used as a mechanism for selecting government leaders according to the people's will and participation. At the same time, elections are also an elite circulation process because they are held periodically or periodically. 
Prasetyoningsih (2014) said, democracy and democratic elections are "qunditio sine qua non," the one can not exist without the others. That is, elections become a procedure for achieving democracy, which in this case transfers people's sovereignty to certain parties to become certain political officials. Therefore, in practice in various democracies, elections are a symbol and measure of the quality of democracy. Dirdjosanjata (2006), said that elections are called democratic if the process and its results occur in a competitive, free, fair, open, and peaceful manner and are felt by political parties and the people. More explicitly, Bisariyadi (2012), said that the basic principle of a democratic state is that every citizen has the right to take an active part in the political process.

Hutington in Rizkiyansyah (2007), states that a country can be called democratic if there is a general election mechanism that is carried out periodically or periodically to conduct elite circulation. While Rizkiyansyah (2007: 3) himself said that the election is one of the most representative institutions in the functioning of democracy. According to him, democracy will not work without elections.

\section{Election of Regional Head (Election) Direct}

The direct election of regional heads (local election) is a process of democratization at the local level, the activities of democracy at the local level, especially for regions that have special characteristics. Direct elections also provide more significant space for the community to be involved in policymaking in the regions. This is important as a process of deepening democracy to realize good and effective governance in the regions. Thus, the election decision was immediately aligned with the spirit of regional autonomy following the local community's aspirations. Therefore, direct elections are believed to be a system that has quite broad implications for developments in the regions.

Another phenomenon is that direct elections, when viewed from the perspective of procedural democracy, have achieved some of the fundamental goals of democracy Lay (2007). First, produce regional heads through democratic election mechanisms (free, fair, and nonviolent). Second, direct elections are a continuation of previous practices (from indirect elections by the DPRD) and, at the same time, lay the foundation for regular elite exchange mechanisms. By Lay (2007), this change has a severe impact on local politics and investment in deepening democracy. Third, direct elections have laid a new foundation for the continuation of the process of political education more broadly. Direct elections are considered to be educated about normality from losing and winning in honest and fair contestation. On the same occasion, Lay also said that the direct election activity was a follow-up to the operation of the democratic principle of individual freedom and equality in politics. Besides, the direct election is also an extension of the will of a decentralized and diverse society. Moreover, the direct local 
election process is carried out in the context of a unique community according to the characteristics of each region.

In line with Lombard's (2000) testimony in Lay (2007), the direct election has actually been a long-standing Indonesian rural tradition. Therefore, Diamond (1996) said that direct elections are the right instrument for deepening democracy (deepening democracy ) and efforts to realize good and effective governance. Hanafi (2014). While Zuhro sees that the deepening of democracy is used to overcome the weaknesses of substantive democracy in responding to local communities'. Hanafi (2014) also say that deepening democracy is needed to fulfill the central idea of political democracy. Thus, the direct elections provide space for many people to be involved in the policy process in the local government as well as the broader involvement of citizens. Stewart (1996).

However, in practice, it cannot be denied the implementation of direct local elections in Indonesia until now; there are still some slanted notes. Nuryanti (2013) said that direct elections have several advantages, including inviting public participation openly and massively, abolishing the subjectivity and monopoly of the DPRD, the people get political education directly, and the possibility of leaders from various layers of society and groups to be different. Riswanda Imawan (2005), in Margono, said that direct elections have the potential to make the government slow and unresponsive, especially if the politics of reciprocity remain implemented.

Nor can the direct local elections automatically eliminate various problems regarding money politics, intimidation, violence, and anarchy. Amirudin and Bisri (2006) even said, in some cases, the election through the DPRD would be better because it could anticipate conflicts and collective violence. Although, substantially, Amirudin and Bisri acknowledged that, however, it cannot be denied, that in practice the implementation of direct local elections in Indonesia until now there are still some skewed notes. Nuryanti (2013) said direct elections had several advantages, including inviting open and massive public participation, abolishing the subjectivity and monopoly of the DPRD, the people getting political education directly, and the possibility of leaders from various walks of life and groups coming up. In contrast to this, Riswanda Imawan (2005), in Margono, said that direct elections have the potential to make the government slow and unresponsive, especially if the politics of reciprocity remain implemented.

Nor can the direct local elections automatically eliminate various problems regarding money politics, intimidation, violence, and anarchy. Amirudin and Bisri (2006) even said, in some cases, the election through the DPRD would be better because it could anticipate conflicts and collective violence. Although, substantially, Amirudin and Bisri claimed that direct and open local elections were far better than using representative institutions. This is inseparable from the various corruption cases that befell the regional head of the election results directly. The high cost of becoming a 
regional head candidate makes elected candidates try to return capital by outsmarting the use of the Regional Budget and other detrimental practices.

\section{METHOD}

This research method uses a qualitative analysis method, where the process of qualitative research by investigators conducted by way of asking questions relevant to the topic. Character $t$ of qualitative research is a holistic account. The researcher seeks to perform a complete study of the research problem so that the study is carried out in many aspects. In this way, the research is expected to be able to visualize the problem clearly and thoroughly.

\section{RESULTS AND DISCUSSION}

\section{Look for the Ideal Governor and Deputy Governor}

Discussions about the election of governors and vice governors for some circles are indeed quite intense. This is inseparable from the fact that, first, the governor is an extension of the central government in the region and, at the same time as the head of government in the region. Second, the election of vice-governor (and vice-regent, vice mayor of the city ) is not described in detail in the legislation. His job was considered less strategic because he was only an assistant to the governor. Third, many facts show the emergence of estrangement between the regional head and deputy regional head in general, as well as the governor and deputy governor in particular. This problem can be fatal to the running of the government.

According to the law and the needs of the people, the three facts above are the gateways in opening new discourses, especially in the election of the ideal governor and vice-governor. Regarding the election of governors, for example, by looking at its dual function, many parties hope that the qualifications and selection of candidates for governors can be tightened. For example, it must go through cadre schools conducted by political parties or by the central government.

By various sources, the intended leadership school training can be carried out by political parties, specially formed independent institutions, or by the central government. It is essential to remember that Indonesia consists of 34 provinces, which spread very broads and need to be built competency and character according to the characteristics of each region. With this, the governor is expected to develop the region following the local's wisdom and still be able to perform tasks of the central government. It is also necessary for the candidate minister and candidate for regent or mayor. Besides, by looking at its strategic functions, some parties even expect the governor to be elected by the president, such as a minister. This is inseparable from the fact that the governor is also an extension of the central government in the regions. 
Another thing that also needs to be considered is the existence of assessments from academics and experts to assess their leadership capacity. For example, by conducting special tests for governor candidates related to government knowledge, regional locality, and leadership. Other demands that also emerge in the field are associated with the transparency of political parties in selecting candidates. The community feels that the process of choosing candidates so far has been elitist and dependent on Jakarta.

In more detail, based on constitutional facts and experience on the ground, many parties also agreed on the idea that the election of the governor and deputy governor was not carried out in one package. This follows various facts that say that the governor and deputy governor often cannot walk together and are only intimate when campaigning. Meanwhile, after being elected, the relationship between the two experienced a gap. The idea that developed was that the governor was still elected through a direct election mechanism but with various requirements listed above. While the deputy governor can be chosen through several alternatives. For example, through the mechanism for the governor's submission to the DPRD and the Ministry of Home Affairs.

Another alternative that also emerged was that the deputy governor was appointed from an ASN cadre who fulfilled his government experience and understood the characteristics of the local community. This issue arose following various government problems. However, it cannot be denied; several parties agree with the election of a package between the governor and deputy governor. The spirit is also inseparable from various facts that require the governor's change in the middle of his term of office. For example, when a governor is caught in a corruption case or entangled in other legal matters that require the deputy to become a regional head.

\section{Initiating the Ideal Model of the Provincial Election}

The direct election of regional heads is an activity of democracy at the local level, especially for regions that have special characteristics. Direct elections also provide greater space for the community to be involved in policymaking in the regions. This is important as a process of deepening democracy to realize good and effective governance in the regions. It is hoped that the elections will be immediately aligned with the spirit of regional autonomy following the aspirations of the local community. Therefore, direct elections are believed to be a system that has quite broad implications for developments in the regions.

The election of regional heads is still a hot debate. It is Both at the level of officials and by the community. This is inseparable from the disappointment of various parties because many of the direct election results of regional heads did not perform well. The legitimacy of the people towards elected regional leaders was low. The simplest indicator is seen from the involvement and participation in choosing the 
community in each provincial head election. However, mistakes about selecting candidates who have low performance cannot be separated from the community's role when voting. In many direct elections, community participation in voting is still quite small. By some parties, participation can be lower if the candidate pairs do not want to give "gas money." However, on the other hand, the provision of gasoline money is also a simalakama fruit for voters because they do not pay attention to the background of the candidate and only see the assistance provided during the campaign. This condition is destroying democracy at the local level.

Apart from the various problems regarding the implementation of the direct local election above, this research strongly believes that the direct local election is the best system for strengthening people's sovereignty. The application of direct local elections also reflects the democratic meaning, as stated in the 1945 Constitution. The thing that needs to be done is to evaluate and reconstruct so that the implementation of direct local elections can be of higher quality.

Looking at the various problems above, this section is here to measure the ideal model of direct local elections, especially at the provincial level, by taking a case study on the Election of the Governor and Deputy Governor of Southeast Sulawesi in 2018. This process is different from that carried out by the LIPI, which looks at the HDI level and regional financial capacity. In this study, the ideal model for the implementation of local elections is directly seen from the political dynamics at the stages of the election.

If the use of indicators set by LIPI, Southeast Sulawesi Province entered at level IV, the direct election can continue to operate, but with the possibility of going to much trouble. This is inseparable from the Southeast Sulawesi HDI condition, which has just risen from low to moderate with 70.61 points. While Southeast Sulawesi's financial capability, when viewed from the ratio of PAD to income, still reaches $21 \%$, and the ratio between transfer funds to total revenue is above $75 \%$. This condition also shows that financial capacity in Southeast Sulawesi is still very dependent on the outside world. Whereas when referring to Dewi (2016), transparency is not right, elitist responsiveness, effectiveness and efficiency, and public accountability in Southeast Sulawesi are also not proper.

By referring to the various findings and discussion above, especially regarding the dynamics of the election of governors and deputy governors as well as the dynamics in the regions after the election process, this study seeks to provide several alternative models of the election of governors and vice governors in Southeast Sulawesi Province. This model can also be adopted by other provinces in Indonesia by keeping in view the characteristics and political dynamics that occur at the time of the election. Besides, further research is also needed so that the proposed model cannot be separated from the characteristics of the area.

First, the need to make improvements in the stages of the direct elections as a whole, both in the stages of pre-election to post-election. For example, by increasing the 
capacity of local election organizers at the lower levels, particularly sub-districts, villages and polling stations, maximizing the supervision system in each stage of the direct election, and reinforce the sanctions imposed on each violation. Besides, it is also necessary to reconsider the conditions for submitting disputes to the Constitutional Court. On the one hand, filing a dispute to the Court became a new culture in the direct local election process. On the other hand, many violations of the election process have been proven legally but failed to be tried at the Constitutional Court because of the maximum difference in the sura. Therefore, it is necessary to reconsider the terms of violations that can be heard in the Constitutional Court.

Second, the need to use information technology to increase transparency, accountability, and efficiency. Starting from the pre-collection process (registration, socialization, verification, and campaign), the voting process, and the post-voting process, namely counting and determining. The maximum utilization of information technology is considered to maintain the authenticity of the voters' votes and the process of calculating the votes more quickly and accurately. The use of information technology can also be used to overcome the complexities of the elections as well as solutions to solve various problems of KPPS officers in various polling stations.

Third, the need to rethink the design of direct elections at the provincial level by paying attention to the role of the governor, both as the head of the regional government and as an extension of the central government in the region. On the other hand, the deputy governor is often only used as a panning and complementary voice during the election process, and less prestige with the governor when he was elected. If referring to Law Number 23 of 2014, the task of the deputy governor is also only as an assistant to the governor, not as a companion.

Based on these dynamics, this study provides an alternative filling of governors and vice governors. The first alternative, the governor, as the regional head at the provincial level, is directly elected by the people but with tightened conditions. For example, it must participate in cadre formation in political parties and by the central government or authorized institutions. This is important to ensure that regional head candidates have an understanding of government and nationality. The deputy governor's position can be done through several alternatives, For example, by being proposed by the governor to the DPRD/Ministry of Home Affairs to be selected or taken from the ASN by looking at career paths in government. However, it must be ensured that the proposed vice governor has experience in government and sufficient knowledge of the region's characteristics and culture. The alternative advantage is that the regional head politically retains the power of the central government and the legitimacy of the people. Technically, the regional policy heads are assisted by representatives who have mature experience in governance. The function of the deputy governor as an assistant to the governor also does not violate Law Number 23 of 2014 concerning the Regional Government. This is important to ensure the running of the 
government can run sustainably and following procedures. However, the consequence is that strict rules are needed that prohibit ASN from being actively involved in practical politics. If proven to be involved, then severe sanctions must be given. To its extreme, ASN (especially bureaucrats) are not given voting rights like the TNI / Polri to ensure that there is no bureaucratic politicization that impedes public services.

The second alternative is to tighten the conditions for nominating the governor and deputy governor. These requirements among others, for example, should have followed the cadres of political parties, have experience and knowledge about local government as evidenced through the feasibility test in writing and interview, an indigenous people within a certain time have lived and settled in the territory of the province and hope to understand about the problems and potential of the region. These conditions are essential to ensure the candidate pair already has the government's provision and can map regional issues and ensure that they have a clear concept of development to maximize regional potential. So that the strategic function of the governor can still be implemented, and the role of the deputy governor can also be optimized.

\section{E. CONCLUSION}

Reflecting on the political dynamics that occurred in the election of the Governor and Deputy Governor of Southeast Sulawesi Province in 2018, this study encourages three alternative models of the election. This alternative model is designed based on the conditions and dynamics in Southeast Sulawesi. Therefore, this alternative model is specifically designed for the election of the Governor and Deputy Governor of Southeast Sulawesi Province in the future. However, this alternative model can still be used in other provinces with the same political characteristics and dynamics as Southeast Sulawesi, with an in-depth study.

Three alternative models for the election of governor and deputy governor of Southeast Sulawesi Province are encouraged in this study, namely: 1). The election of governors and deputy governors is directly elected by the people. However, the government must make improvements at the overall election stage for the governor and deputy governor. Besides, this research also encourages the maximum utilization of information technology to increase transparency, accountability, and efficiency. 2). The governors and deputy governors are directly elected by the people by tightening the conditions for nominating the governor and deputy governor. These requirements include: must have followed the regeneration of political parties, have experience and knowledge of local government as evidenced by written feasibility tests and interviews, are indigenous people who in a certain period have lived and settled in the province with the hope that they can understand about the problems and potential of the region. These conditions are essential to ensure the candidate pair already has the provision of government and regional map issues and ensure that they have a clear concept of 
development to maximize regional potential. 3). As regional head at the provincial level, the governor is directly elected by the people by tightening the nomination requirements, such as having to attend the regeneration of political parties and the school of leadership. While the position of the deputy governor is elected through a mechanism proposed by the governor to the DPRD/Ministry of Home Affairs to be selected or through a position auction with

\section{REFERENCES}

1. Akbar, I. (2016). Pilkada serentak dan geliat dinamika politik dan pemerintahan lokal Indonesia. CosmoGov: Jurnal Ilmu Pemerintahan, 2(1), 95-110.

2. Amirudin \& Zaini, B. (2006). Pilkada Langsung Problem dan Prospek: Sketsa Singkat Perjalanan Pilkada 2005. Yogyakarta: Pustaka Pelajar.

3. Bisariyadi, B., Triningsih, A., \& Rahmawaty, M. (2016). Komparasi Mekanisme Penyelesaian Sengketa Pemilu di Beberapa Negara Penganut Paham Demokrasi Konstitusional. Jurnal Konstitusi, 9(3), 531-562.

4. Central Statistics Agency of Southeast Sulawesi. (2018). Provinsi Sulawesi Tenggara Dalam Angka 2018. Sulawesi Tenggara: BPS.

5. Central Statistics Agency of Southeast Sulawesi. (2019). Provinsi Sulawesi Tenggara Dalam Angka 2019. Sulawesi Tenggara: BPS.

6. Chalid, P. (2005). Pilkada Langsung: Demokratisasi Daerah dan Mitos Good Governance. Jakarta: Partnership

7. Creswell, J. W. (2013). Research Design: Pendekatan Kualitatif, Kuantitatif dan Mixed. Yogyakarta: Pustaka Pelajar.

8. Dahl, R. A. (1982). Dilemmas of Pluralist Democracy: Autonomy ws Control. Yale University Press.

9. Dahl, R. (1989). Democracy and Its Cristics. Yale: Yale University Press

10. Diamond, L. (1996). Developing Democracy toward Consolidation. London: The John Hopkins University Press.

11. Dirdjosanjata, P., \& Kana, N. L. (2006). Demokrasi dan Potret Lokal Pemilu 2004. Yogyakarta: Pustaka Pelajar.

12. Effendy, K. (2010). Memadukan Metode Kuantitaf dan Kualitatif. Bandung: Indra Prahasta.

13. Gaffar, A. (1999). Politik Indonesia: Transisi Menuju Demokrasi. Yogyakarta: Pustaka Pelajar.

14. Government Regulation in Lieu of Law Number 1 Year 2014 Regarding the Election of Governors, Regents and Mayors.

15. Hanafi, R. I. (2014). Direct Eletion for Local Leaders in Indonesia: Some Critical Notes for Political Parties. Jurnal Penelitian Politik LIPI, 11(2), 1-16.

16. Kristiadi. J. (2006). Darurat Partai Politik. Jakarta: Ghalia Indonesia.

17. Law Number 22 Year 2014 Regarding the Election of Governors, Regents and Mayors. 
18. Law Number 23 of 2014 concerning Regional Government.

19. Law Number 10 of 2016 concerning the Second Amendment to Law Number 1 of 2015 concerning the Establishment of Government Regulations in lieu of Law Number 1 of 2014 concerning the Election of Governors, Regents and Mayors Become Acts.

20. Lay, C. (2000). Antara Anarki dan Demokrasi: Masalah Kekerasan Politik di Indonesia. Jurnal Ilmu Sosial dan Ilmu Politik, 3(3).

21. Lay, C. (2007). Pilkada Langsung dan Pendalaman Demokrasi. Jurnal Ilmu Sosial dan Ilmu Politik, 11(1).

22. Margono, S. (2005). Reformasi Administrasi dan Paradoks Demokrasi. Jurnal Ilmu Sosial dan Ilmu Politik, 9(1).

23. Mariana, D. (2009). Dinamika Demokrasi dan Perpolitikan Lokal di Indonesia. Bandung: Penerbit AIPI Bandung

24. Marijan, K. (2010). Sistem Politik Indonesia: Konsolidasi Demokrasi Pasca-Orde Baru. Jakarta: Kencana Prenada Media Group

25. Nuryanti, S. (2013). Evaluasi Format Pemilukada Menuju Tata Kelola Pemerintahan yang Baik dan Efektiv di Tingkat Kabupaten/ Kota. Jurnal Ilmu Politik, 10(1).

26. Nuryanti, S. (2015). Intervensi Penyelenggaraan Pemilukada: Regulasi Sumberdaya dan Eksekusi. Jurnal Ilmu Sosial dan Ilmu Politik, 19(2).

27. Pahlevi, I. (2011). Pemilihan Gubernur secara Demokratis: Studi terhadap Gagasan Dipilih Kembali oleh DPRD di Provinsi Bengkulu. Jurnal DPD RI, 16(2).

28. Usman \& Megawati, C. (2017). Dinamika Politik: Solusi Akhir Eksistensi Konflik dan Pengaruhnya terhadap Masyarakat Pasca Perdamaian di Aceh Besar. Jurnal Humaniora, 1 (2), 79-86. 